\title{
The Structure of Insoluble Pectinates and Alginates of Polyvalent Metals Based on IR Spectra Data
}

\section{Nelli Shalikovna Kajsheva, Alexander Shalikovich Kajshev, Anna Borisovna Samoryadova, Sergey Vasilyevich Volokitin, Christina Nicolaevna Gulbjakova, Ekaterina Alexandrovna Maslovskaya}

Pyatigorsk Medical and Pharmaceutical Institute-A Branch of Federal State-Funded Educational Institution of Higher Vocational Education "Volg SMU”, Pyatigorsk, Russia

Email: caisheva2010@yandex.ru

How to cite this paper: Kajsheva, N.S., Kajshev, A.S., Samoryadova, A.B., Volokitin, S.V., Gulbjakova, C.N. and Maslovskaya, E.A. (2017) The Structure of Insoluble Pectinates and Alginates of Polyvalent Metals Based on IR Spectra Data. American Journal of Analytical Chemistry, 8, 334344 .

https://doi.org/10.4236/ajac.2017.85025

Received: April 3, 2017

Accepted: May 12, 2017

Published: May 15, 2017

Copyright () 2017 by authors and Scientific Research Publishing Inc. This work is licensed under the Creative Commons Attribution International License (CC BY 4.0).

http://creativecommons.org/licenses/by/4.0/

\begin{abstract}
Using the method of IR spectroscopy it was ascertained that in pectinates and alginates of polyvalent metals the coordination bonds between cations $\mathrm{Pb}^{2+}$, $\mathrm{Cu}^{2+}, \mathrm{Zn}^{2+}, \mathrm{Cr}^{3+}, \mathrm{Mn}^{2+}, \mathrm{Fe}^{2+}, \mathrm{Co}^{2+}, \mathrm{Ni}^{2+}$ and the oxygen atoms of carboxyl and hydroxyl groups, pyranose cycle and glycosidic linkage of polyuronides, the water molecules are formed. It was also ascertained that $\mathrm{Cu}^{2+}$ cations form asymmetrical structures with carboxyl groups of polyuronides (monodentate ligands) and cations of other metals-symmetrical structures with carboxyl groups of polyuronides (bidentate ligands).
\end{abstract}

\section{Keywords}

Coordination Compounds, Pectinates of Metals, Alginates of Metals, Structure, IR Spectra

\section{Introduction}

The structure of coordination compounds of polyuronides with ions of polyvalent metals (polyuronates of metals) in solid state does not have an unambiguous interpretation due to the presence of several electron-donating atoms of oxygen able to coordinate with the ions of metals and due to the inclination to form coordination compounds of different forms (tetrahedrons, octahedrons) by the pyranose cycles of polyuronides [1] [2]. We believe that the most acceptable method of the ascertainment of the structure of insoluble polyuronates of metals is the method of IR spectroscopy while using which certain atomic bunching of polyuronates may cause the appearance of a great number of informative dis- 
crete lines and bands in vibrational spectra.

The goal of this research is to study the structure of the pectinates and alginates $\mathrm{Cu}^{2+}, \mathrm{Zn}^{2+}, \mathrm{Pb}^{2+}, \mathrm{Cr}^{3+}, \mathrm{Mn}^{2+}, \mathrm{Fe}^{2+}, \mathrm{Co}^{2+}, \mathrm{Ni}^{2+}$ which are insoluble in water using the method of IR spectroscopy.

\section{Experimental}

\subsection{Materials}

The objects of this research were pectin, the sodium alginate and the products of their interaction with inorganic salts: acetates $\mathrm{Cu}^{2+}, \mathrm{Pb}^{2+}, \mathrm{Cr}^{3+}$, sulphates $\mathrm{Fe}^{2+}$, $\mathrm{Zn}^{2+}, \mathrm{Mn}^{2+}$, chloride $\mathrm{Co}^{2+}$, nitrate $\mathrm{Ni}^{2+}$.

The pectin produced by experimental engineering technological bureau "Mars" (Nalchik) from the sugar beet marc and corresponding to the regulations of temporary pharmacopoeic article Temporary Pharmacopoeia article 42-343399 "Pectin" is a polymer featuring average molar mass of $3200 \mathrm{~kg} / \mathrm{mol}$ consisting of $1 \rightarrow 4$-bound remnants of $\alpha$-D-galacturonic acid containing $14.4 \%$ of free carboxyl groups, $9.2 \%$ of methylated carboxyl groups. The content of total ash is $1.4 \%$, the content of ash insoluble in $10 \%$ hydrochloric acid is $0.4 \%, \mathrm{pH}$ of $2 \%$ water solution is 3.5 , the water dissociation constant is $3.2 \times 10^{-4}$ [3].

Sodium alginate produced by experimental algal plant (Arkhangelsk) from the fronds of sacchariferous laminaria and corresponding to the regulations of State all-Russian standard 26185-84 "Seaweeds, sea grass and the products of their processing. The methods of analysis" is polymer featuring average molar mass of $89700 \mathrm{~kg} / \mathrm{mol}$ consisting of alternating blocks of $1 \rightarrow 4$-bound remnants of $\beta$-Lguluronic acid and $\alpha$-D-mannuronic acid with molar ratio 1:2 [4] [5]. The content of total ash is $25.7 \%$, the content of ash insoluble in $10 \%$ hydrochloric acid is $0.8 \%, \mathrm{pH}$ of $1 \%$ water solution is 7.6 , the water dissociation constant is $2.5 \times$ $10^{-8}[4]$.

Inorganic salts with Pro Analysi (p.a.) purity qualification were used in the research.

\subsection{The Method of Obtaining Polyuronates Metals}

The jellous sediments of polyuronates of metals were obtained by mixing water solutions of pectin $\left(5.0 \times 10^{-3} \mathrm{~mol} / \mathrm{l}\right)$ previously neutralized by $2.0 \mathrm{~mol} / \mathrm{l}$ water solution of ammonia up to $\mathrm{pH} \sim 8$, or solutions of sodium alginate $\left(5.0 \times 10^{-3}\right.$ $\mathrm{mol} / \mathrm{l}$ ) with $4.5 \times 10^{-2}$ water solutions of inorganic salts with volume ratio $1: 1$. For almost complete sedimentation reaction mixtures were treated with $96 \%$ ethanol (1:2), kept at indoor temperature (2 hours), the sediments were extracted by filtration, flushed by water till the neutral reaction of rinsing water and dried at temperature $60^{\circ} \mathrm{C} \pm 5^{\circ} \mathrm{C}$ till fixed mass [6].

\subsection{Conditions of the Analysis by the Method of IR-Spectroscopy}

IR absorption spectra of $10 \%$ suspensions of polyuronides and polyuronates of metals in liquid petrolatum were registered at $4000-400 \mathrm{~cm}^{-1}$ at Infrared Spec- 
trometer-40 spectrophotometer [7]-[12]. The observed shifts of absorption stripes, the change of intensity of absorption bands and the energy of hydrogen bond were the objects of study. The relative error of definitions $(n=7)$ is $3.4 \%-4.8 \%$.

\section{Results and Discussion}

The pectinates of polyvalent metals. The characteristic absorption bands in IR spectra of pectinates of metals in comparison with pectin are given in Table 1 .

Table 1. Characteristic absorption bands $\left(\mathrm{cm}^{-1}\right)$ in IR spectra of metal pectinates.

\begin{tabular}{|c|c|c|c|c|c|c|c|c|c|}
\hline Pectin & $\begin{array}{c}\text { Pectinate } \\
\mathrm{Cu}^{2+}\end{array}$ & $\begin{array}{l}\text { Pectinate } \\
\mathrm{Ni}^{2+}\end{array}$ & $\begin{array}{c}\text { Pectinate } \\
\mathrm{Co}^{2+}\end{array}$ & $\begin{array}{c}\text { Pectinate } \\
\mathrm{Zn}^{2+}\end{array}$ & $\begin{array}{c}\text { Pectinate } \\
\mathrm{Mn}^{2+}\end{array}$ & $\begin{array}{c}\text { Pectinate } \\
\mathrm{Pb}^{2+}\end{array}$ & $\begin{array}{c}\text { Pectinate } \\
\mathrm{Fe}^{2+}\end{array}$ & $\begin{array}{c}\text { Pectinate } \\
\mathrm{Cr}^{3+}\end{array}$ & $\begin{array}{l}\text { Probable rating of bands } \\
{[9][11]^{*}[12]^{*}[13]}\end{array}$ \\
\hline 1 & 2 & 3 & 4 & 5 & 6 & 7 & 8 & 9 & 10 \\
\hline 3760 & $\begin{array}{c}\text { 3990; } 3968 \text { w.; } \\
3762\end{array}$ & & & 3829 & $3885 ; 3769$ & & & $3944 ; 3864$ & \\
\hline 3450 & $3560 \mathrm{w}$. & $3528 \mathrm{w}$. & 3530 & 3530 & 3515 & 3510 & 3452 & 3472 & \\
\hline 3415 & 3440 & 3430 & 3430 & 3415 & 3420 & 3422 & 3415 & 3430 & \\
\hline $3380 \mathrm{~s}$. & 3434 wi., w. & 3390 & 3395 & 3395 & $3360 \mathrm{~s}$. & $3385 \mathrm{~s}$. & 3381 wi., w. & 3396 & $\begin{array}{l}v(\mathrm{OH}, \text { associated } \\
\text { by intramolecular }\end{array}$ \\
\hline $3350 \mathrm{~s}$ & $3354 \mathrm{w}$. & $3358 \mathrm{~s}$ & $3360 \mathrm{~s}$ & $3363 \mathrm{~s}$ & $3351 \mathrm{~s}$. & $3355 \mathrm{~s}$. & 3352 & 3376 & hydrogen binding) \\
\hline $3275 \mathrm{~s}$ & 3295 & $3280 \mathrm{~s}$ & 3285 & 3282 & 3290 & 3300 & $3258 \mathrm{w}$. & 3295 & \\
\hline 3241 & 3250 & & & & 3243 & & & 3245 & \\
\hline $3204 \mathrm{w}$. & 3218 & 3207 & 3207 & 3210 & $3208 \mathrm{w}$. & 3210 & $3204 \mathrm{w}$. & 3213 & $\delta(\mathrm{CH})$ \\
\hline 3180 & $3192 \mathrm{~s}$. & 3185 & $3188 \mathrm{~s}$. & $3190 \mathrm{~s}$. & 3184 & 3180 & 3185 & 3190 & \\
\hline $2874 ; 2823$ & 2880 w.; 2825 & 2825 & 2825 & 2880 & 2825 & 2830 & 2825 & 2825 & $v(\mathrm{CH})$ \\
\hline 2740 wi., s. & 2738 & 2732 & 2736 & 2740 & 2737 & 2738 & 2733 & 2738 & $v\left(\mathrm{O}_{6} \mathrm{H}-\right.$ of carboxyl groups $)$ \\
\hline $1710 \mathrm{w}$. & $1752 \mathrm{w} . ; 1720 \mathrm{w}$. & 1730 & $1732 \mathrm{w}$. & $1735 \mathrm{w}$. & $1735 \mathrm{w}$. & $1725 \mathrm{w}$. & $1729 \mathrm{w}$. & 1730 & $v_{\mathrm{as}}(\mathrm{C}=\mathrm{O}$ of ester groups $)$ \\
\hline $1630 \mathrm{w}$. & $1615 \mathrm{w}$. & $1615 \mathrm{w}$. & $1610 \mathrm{~s}$. & $1613 \mathrm{w}$. & $1600 \mathrm{~s}$. & $1581 \mathrm{w}$. & $1606 \mathrm{~s}$ & $1620 \mathrm{w}$. & $v_{\mathrm{as}}\left(\mathrm{COO}^{-}\right)$ \\
\hline $1405 \mathrm{w}$. & $1400 \mathrm{~s}$. & $1415 \mathrm{~s}$. & $1410 \mathrm{~s}$. & $1421 \mathrm{~s}$. & $1415 \mathrm{~s}$. & $1411 \mathrm{w}$. & $1421 \mathrm{~s}$. & $1430 \mathrm{~s}$. & $v_{\mathrm{s}}\left(\mathrm{COO}^{-}\right)$ \\
\hline $1600 \mathrm{~s}$. & $1605 \mathrm{w}$. & $1602 \mathrm{w}$. & $1602 \mathrm{w}$. & $1605 \mathrm{w}$. & $1607 \mathrm{w}$. & 1602 & $1608 \mathrm{w}$. & $1605 \mathrm{w}$. & $\delta\left(\mathrm{H}_{2} \mathrm{O}\right)$ \\
\hline $1475 \mathrm{w}$. & 1470 & & & & & & & 1470 & $\delta(\mathrm{OCH})+\delta(\mathrm{CCH})$ \\
\hline $1460 \mathrm{~s}$. & 1446 & 1448 & 1468 & 1459 & 1450 & 1445 & 1466 & 1460 & $\delta(\mathrm{CCH})+\delta(\mathrm{COH})$ \\
\hline $1350 \mathrm{~s}$. & 1378 & 1376 & 1372 & 1370 & 1378 & 1382 & 1379 & 1378 & $\delta(\mathrm{CCH})+\delta(\mathrm{COH})$ \\
\hline $1225 \mathrm{~s}$. & 1235 & 1230 & 1240 & 1240 & 1235 & 1227 & 1227 & 1233 & $v\left(\mathrm{COO}^{-}\right)$ \\
\hline 1196 & $1156 \mathrm{~s}$. & $1196 \mathrm{s.}$ & $1156 \mathrm{~s}$. & $1154 \mathrm{~s}$. & $1190 \mathrm{~s}$. & $1196 \mathrm{s.}$ & $1196 \mathrm{~s}$. & $1196 \mathrm{~s}$. & $v(\mathrm{C}-\mathrm{C}$ of pyranose cycle $)$ \\
\hline 1145 & 1120 & 1140 & 1135 & 1136 & 1140 & 1140 & 1143 & 1130 & $\begin{array}{c}v(\text { CO of pyranose cycle })+ \\
v(\text { CO of glycosidic linkage })\end{array}$ \\
\hline $1032 ; 924$ & $1024 ; 966$ & $1052 ; 936$ & $1021 ; 960$ & $1053 ; 969$ & $1053 ; 969$ & $1053 ; 929$ & $1053 ; 929$ & $1052 ; 912$ & $v(\mathrm{CO}$ of pyranose cycle $)$ \\
\hline 844 & 845 & 846 & 848 & 846 & 845 & 844 & 844 & 852 & $v(\mathrm{CO}$ of $\alpha$-glycosidic linkage $)$ \\
\hline 1 & 2 & 3 & 4 & 5 & 6 & 7 & 8 & 9 & 10 \\
\hline $\begin{array}{c}780 ; 720 \\
628\end{array}$ & $\begin{array}{l}778 ; 722 ; \\
620\end{array}$ & $\begin{array}{l}778 ; 720 ; \\
632\end{array}$ & $\begin{array}{c}781 ; 724 \\
628\end{array}$ & $\begin{array}{c}778 ; 721 \\
626\end{array}$ & $\begin{array}{c}782 ; 724 \\
630\end{array}$ & $\begin{array}{c}780 ; 752 \\
637\end{array}$ & $\begin{array}{l}778 ; 717 ; \\
630\end{array}$ & $778 ; 748$ & $\delta(\mathrm{CH})$ \\
\hline $592 ; 567$ & $555 ; 540$ & $570 ; 560$ & $570 ; 550$ & $581 ; 553$ & 590 & 590 & $575 ; 560$ & $590 ; 567$ & $\delta\left(\mathrm{H}_{2} \mathrm{O}\right) \chi(\mathrm{CO})$ \\
\hline
\end{tabular}

Notes: "s.”, strong absorption intensity; “w.”, weak absorption intensity; “wi.”, wide stripe; "s”, symmetrical vibrations; "as”, asymmetrical vibrations; “ $\chi$ ", inner vibrations. ${ }^{*}$ The data received by the authors are especially reliable as initially they had been studying the IR spectra of monosaccharide metal complexes the structure of which was defined by the method of X-ray structural analysis, and they applied the received assignments to the crystalline structures which are isomorphic with the initial ones. 
The most characteristic spectral region in which one can distinguish substantial differences in the character and intensity of absorption bands in IR spectra of pectin and pectinates refers to $3400-3100 \mathrm{~cm}^{-1}$ range belonging to the valence vibrations of hydroxyl groups. Besides that, the absorption in the more longwave area was observed for the pectinates of metals which is characteristic for different in energy two- and three-centered donor-acceptor hydrogen bonds of hydroxyl with hydroxyl or substituted hydroxyl [7]:<smiles>[R]O[Hg]O[R]([R])O[R]</smiles>

The vibration interaction of oscillators of bound pectins can be the cause of band splitting in $4000-3000 \mathrm{~cm}^{-1}$ area. The hydroxyl groups associated by donor-acceptor hydrogen bonds form a system of bound oscillators which are very sensitive to the external field disturbance. While introducing metal cations onto the pectin molecule in IR spectra the bands shifts of valence vibration of hydroxyl groups into the long-wafe area is observed. That means that a bond breakage or a weakening of hydrogen bonds by metal ions took place while forming the coordination particles. Such spectral changes were observed for the pectinates of all metals. The strongest shift noted took place in the presence of $\mathrm{Cu}^{2+}$ cations.

A great number of stripes of valence vibrations of hydroxyl groups, a sufficient frequency range which all these stripes appear in testify a wide set of energy-wise unequivalent hydrogen bonds in the studied pectinates. Long-wave stripes $v(\mathrm{OH})$ experience the most sufficient shift. Taking into account that a high frequency shift of valence vibrations of hydroxyl groups associated by hydrogen groups $\left(v_{\mathrm{i}}\right)$ concerning the vibration frequency of free hydroxyl groups $\left(v_{\mathrm{cB}}=3636 \mathrm{~cm}^{-1}\right)$ is proportional to the energy of hydrogen bonds $\left(\mathrm{U}_{\mathrm{BC}}\right)$ [7]:

$$
\left(v_{c B}-v_{i}\right) / v_{c B}=k U_{B C}
$$

in which $\mathrm{k}$ is the coefficient of proportionality which for hexapyranosides is $9 \times$ $10^{-3} \mathrm{~mol} / \mathrm{kJ}$ [7]), we have calculated the values of the energy of hydrogen bonds in molecules of the pectinates under study (Table 2).

In order to reveal the correlation between the absorption bands of hydroxyl groups associated by hydrogen bond and the energy values of hydrogen bonds in the pectinates of metals in the graphic system " $v_{i}=f\left(-U_{B C}\right)$ " linear relationship $y$ $=a+b x$, где $a=111.11, b=-3.06 \times 10^{-2}$ was obtained. This testifies a reliable correlation of energy of hydrogen bonds with the experimental sizes of absorption bands of hydroxyl groups of pectinates which form associates. The series of metal ions in pectinates in the order of their influence on the attenuation of energy of hydrogen bonds is as follows: $\mathrm{Cu}^{2+}>\mathrm{Co}^{2+}>\mathrm{Zn}^{2+}>\mathrm{Ni}^{2+}>\mathrm{Cr}^{3+}>$ $\mathrm{Mn}^{2+}>\mathrm{Pb}^{2+}>\mathrm{Fe}^{2+}$.

The most significant band sift at $3350 \mathrm{~cm}^{-1}$ is caused by $\mathrm{Cr}^{3+}, \mathrm{Zn}^{2+}, \mathrm{Co}^{2+}, \mathrm{Ni}^{2+}$ ions; the band shift at $3275 \mathrm{~cm}^{-1}$ is caused by $\mathrm{Cu}^{2+}, \mathrm{Cr}^{3+}, \mathrm{Pb}^{2+}, \mathrm{Mn}^{2+}$ ions; the band shift at $3180 \mathrm{~cm}^{-1}$ is caused by $\mathrm{Cu}^{2+}, \mathrm{Cr}^{3+}, \mathrm{Zn}^{2+}$ ions.

The second observed area of changes in IR spectra of metal pectin and pectinates refers to $1710 \mathrm{~cm}^{-1}$, this band is due to the absorption of valence vibrations 
Table 2. Characteristics of hydrogen bonds formed by the pectinates of metals.

\begin{tabular}{|c|c|c|c|c|c|c|c|c|c|}
\hline $\begin{array}{c}\text { Band shift and the } \\
\text { energy of ties }\end{array}$ & Pectin & $\begin{array}{c}\text { Pectinate } \\
\mathrm{Cu}^{2+}\end{array}$ & $\begin{array}{c}\text { Pectinate } \\
\mathrm{Ni}^{2+}\end{array}$ & $\begin{array}{c}\text { Pectinate } \\
\mathrm{Co}^{2+}\end{array}$ & $\begin{array}{c}\text { Pectinate } \\
\mathrm{Zn}^{2+}\end{array}$ & $\begin{array}{c}\text { Pectinate } \\
\mathrm{Mn}^{2+}\end{array}$ & $\begin{array}{l}\text { Pectinate } \\
\mathrm{Pb}^{2+}\end{array}$ & $\begin{array}{l}\text { Pectinate } \\
\mathrm{Fe}^{2+}\end{array}$ & $\begin{array}{c}\text { Pectinate } \\
\mathrm{Cr}^{3+}\end{array}$ \\
\hline \multirow{7}{*}{$\begin{array}{l}\text { Band shift compared } \\
\text { to pectin, } \mathrm{cm}^{-1}\end{array}$} & 3450 & +110 & +78 & +80 & +80 & +65 & +60 & +2 & +22 \\
\hline & 3415 & +25 & +15 & +15 & - & +5 & +7 & - & +15 \\
\hline & 3380 & +54 & +10 & +15 & +15 & +20 & +5 & +1 & +16 \\
\hline & 3350 & +4 & +8 & +10 & +13 & +1 & +5 & +2 & +26 \\
\hline & 3275 & +20 & +5 & +10 & +7 & +15 & +25 & -17 & +20 \\
\hline & 3241 & +9 & - & - & - & +2 & - & - & +4 \\
\hline & 3180 & +12 & +5 & +8 & +10 & +4 & - & +5 & +10 \\
\hline \multirow{7}{*}{$\begin{array}{l}\text { Calculated energy of } \\
\text { hydrogen bonds, } \mathrm{kJ} / \text { mole } \\
\text { (absorption bands } \\
\text { OH of groups, } \mathrm{cm}^{-1} \text { ) }\end{array}$} & $5.68(3450)$ & 2.32 & 3.30 & 3.24 & 3.24 & 3.70 & 3.85 & 5.62 & 5.01 \\
\hline & $6.75(3415)$ & 5.99 & 6.30 & 6.30 & 6.75 & 6.60 & 6.54 & 6.75 & 6.30 \\
\hline & $7.82(3380)$ & 6.17 & 7.52 & 7.36 & 7.36 & 8.43 & 7.67 & 7.79 & 7.33 \\
\hline & $8.74(3350)$ & 8.62 & 8.50 & 8.43 & 8.34 & 8.71 & 8.59 & 8.68 & 7.95 \\
\hline & $11.03(3275)$ & 10.42 & 10.88 & 10.73 & 10.82 & 10.57 & 10.27 & 11.55 & 10.42 \\
\hline & $12.07(3241)$ & 11.80 & - & - & - & 12.01 & - & - & 11.95 \\
\hline & $13.93(3180)$ & 13.57 & 13.78 & 13.69 & 13.63 & 13.81 & 13.93 & 13.78 & 13.63 \\
\hline \multirow{7}{*}{$\begin{array}{l}\text { Energy decrease of } \\
\text { hydrogen bonds } \\
\text { compared to pectin, } \\
\mathrm{kJ} / \mathrm{mole}\end{array}$} & & 3.36 & 2.38 & 2.44 & 2.44 & 1.98 & 1.83 & 0.06 & 0.67 \\
\hline & & 0.76 & 0.45 & 0.45 & - & 0.15 & 0.21 & - & 0.45 \\
\hline & & 1.65 & 0.30 & 0.46 & 0.46 & 0.61 & 0.15 & 0.03 & 0.49 \\
\hline & & 0.12 & 0.24 & 0.31 & 0.40 & 0.03 & 0.15 & 0.06 & 0.79 \\
\hline & & 0.61 & 0.15 & 0.30 & 0.21 & 0.46 & 0.76 & 0.52 & 0.61 \\
\hline & & 0.27 & - & - & - & 0.06 & - & - & 0.12 \\
\hline & & 0.36 & 0.15 & 0.24 & 0.30 & 0.12 & - & 0.15 & 0.30 \\
\hline
\end{tabular}

of carbonyl of ester groups. For pectinates this band was observed to shift to the long-wave area for $10-15 \mathrm{~cm}^{-1}$. Concerning the absorption intensity this band is the weakest for all the substances under study.

The third observed area of changes in IR spectra of pectinates refers to the changes of absorption bands of valent asymmetrical and symmetrical vibrations of ionized carboxyl in $1630-1600$ and $1430-1400 \mathrm{~cm}^{-1}$ areas which are the most susceptible to the nature of the metal cation. In this area the absorption bands of carboxyls are overlapped by the bands of deformative two-dimensional vibrations of water $\delta\left(\mathrm{H}_{2} \mathrm{O}\right)$. While in $1630-1600 \mathrm{~cm}^{-1}$ area it is characteristic of pectinates to demonstrate the shift of bands in the direction of low-frequency wavelengths, in $1430-1400 \mathrm{~cm}^{-1}$ area they are shifted in the direction of highfrequence bands in comparison with pectin (Table 3). With the growth of the radius of hydrated metal ions and as a consequence of it with the decrease of the electrostatic field and the polarizing effect of cations, $\Delta v\left(\right.$ as-s $\left.\mathrm{COO}^{-}\right)$value is decreasing. $\Delta v\left(\right.$ as-s $\mathrm{COO}^{-}$) value is $\leq 200 \mathrm{~cm}^{-1}$ for the studied metal pectinates except for $\mathrm{Cu}^{2+}$ pectinate, which testifies the formation of symmetrical structures of metal ions with carboxyl groups of pectin acting as bidentate ligands [9]: 
Table 3. Shift of characteristic absorption bands in IR spectra of metal pectinates.

\begin{tabular}{|c|c|c|c|c|c|c|c|c|c|c|c|c|}
\hline Objects & $\begin{array}{c}v_{\text {as }}\left(\mathrm{COO}^{-}\right) \\
\mathrm{cm}^{-1}\end{array}$ & $\begin{array}{c}v_{\mathrm{s}}\left(\mathrm{COO}^{-}\right) \\
\mathrm{cm}^{-1}\end{array}$ & $\begin{array}{c}\Delta v\left(\text { as-s } \mathrm{COO}^{-}\right) \\
\mathrm{cm}^{-1}\end{array}$ & $\begin{array}{l}v^{*} \\
\mathrm{~cm}^{-1}\end{array}$ & $\begin{array}{l}\Delta v^{* *} \\
\mathrm{~cm}^{-1}\end{array}$ & $\begin{array}{l}v^{* * *}, \\
\mathrm{~cm}^{-1}\end{array}$ & $\begin{array}{c}\Delta v^{* * * *} \\
\mathrm{~cm}^{-1}\end{array}$ & $\begin{array}{c}\mathrm{Ar} \\
{[14]}\end{array}$ & $\begin{array}{l}\mathrm{r}, \AA \\
{[14]}\end{array}$ & $\begin{array}{c}\mathrm{E} \\
{[15]}\end{array}$ & $\begin{array}{c}\mathrm{E} \cdot 10^{6} \text {, un. СГСЭ of } \\
\text { charge, } \mathrm{cm}^{-1}[15]\end{array}$ & $\chi[15]$ \\
\hline Pectin & & & & 924 & & 844 & & & & & & \\
\hline Pectinate $\mathrm{Pb}^{2+}$ & 1581 & 1411 & 170 & 929 & 5 & 844 & - & 207.20 & 2.39 & 0.84 & & 1.9 \\
\hline Pectinate $\mathrm{Cu}^{2+}$ & 1615 & 1400 & 215 & 966 & 42 & 845 & 1 & 63.55 & 2.35 & 0.85 & 2.87 & 1.9 \\
\hline Pectinate $\mathrm{Zn}^{2+}$ & 1613 & 1421 & 192 & 969 & 45 & 846 & 2 & 65.39 & 2.35 & 0.85 & 2.80 & 1.6 \\
\hline Pectinate $\mathrm{Cr}^{3+}$ & 1620 & 1430 & 190 & 912 & -12 & 852 & 8 & 52.00 & 2.33 & 0.86 & & 1.6 \\
\hline Pectinate $\mathrm{Mn}^{2+}$ & 1600 & 1415 & 185 & 969 & 45 & 845 & 1 & 54.94 & 2.35 & 0.85 & 2.59 & 1.5 \\
\hline Pectinate $\mathrm{Fe}^{2+}$ & 1606 & 1421 & 185 & 929 & 5 & 844 & - & 55.85 & 2.35 & 0.85 & & 1.8 \\
\hline Pectinate $\mathrm{Co}^{2+}$ & 1610 & 1410 & 200 & 960 & 36 & 848 & 4 & 58.93 & 2.34 & 0.85 & 2.87 & 1.9 \\
\hline Pectinate $\mathrm{Ni}^{2+}$ & 1615 & 1415 & 200 & 936 & 12 & 846 & 2 & 58.69 & 2.29 & 0.87 & 2.94 & 1.9 \\
\hline
\end{tabular}

Примечание: "s", symmetrical vibrations; "as", asymmetrical vibrations; ${ }^{*} \mathrm{CO}$ of pyranose cycle; ${ }^{* *} \mathrm{CO}$ of pyranose cycle in comparison with pectin; ${ }^{* * *} \mathrm{CO}$ of $\alpha$, glycosidic linkage; ${ }^{* * * *} \mathrm{CO}$ of $\alpha$, glycosidic linkage in comparison with pectin; Ar, relative atomic mass of metal cation; r, thermochemical radius of hydrated metal cation; $\varepsilon$, polarizing effect of metal cation; $\mathrm{E}$, electrostatic field of metal cation; $\chi$, relative electronegativity of metal cation.

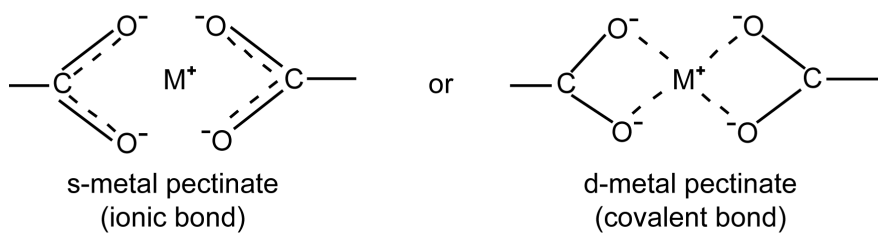

while bonding with $\mathrm{Cu}^{2+}$ ions the carboxyl groups of pectin act as monodentate ligands which is testified by high values of $\Delta v$ (215), and an asymmetrical structure of carboxylates is formed [9]:

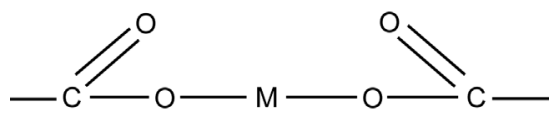

The next area of changes in IR spectra of pectinates refers to the changes of absorption band of valent vibrations of CO of pyranose cycle $\left(924 \mathrm{~cm}^{-1}\right)$ : the most noticeable are the high frequency shifts $\left(36-45 \mathrm{~cm}^{-1}\right)$ for pectinates $\mathrm{Zn}^{2+}$, $\mathrm{Mn}^{2+}, \mathrm{Cu}^{2+}, \mathrm{Co}^{2+}$, which is due to the coordination of ions of the mentioned metals to the oxygen atoms of pyranose cycle characteristic to monomeric hexuronic acid as well [16].

The shift of the absorption band of valent vibrations of $\alpha$-glycosidic linkage $\left(844 \mathrm{~cm}^{-1}\right)$ into the long-wave area is noticeable only for pectinates $\mathrm{Cr}^{3+}$ и $\mathrm{Co}^{2+}$; evidently, the ions of these metals are coordinated to the oxygen atoms of glycosidic centre.

The position of the described bands and the difference of $\Delta v$ frequencies are complex functions of relative atomic masses, thermochemical radii of hydrated ions, the polarizing effect of cations, the electrostatic field and the relative electronegativity of metal ions.

Comparing the intensity of the absorption band at $1600 \mathrm{~cm}^{-1}$ one can notice a significant weakening of the intensity of that band at pectinates which can be referred to the insignificant quantity or absence of crystallized water competing 
with pectins for the coordination with the metal ion.

It is evident that from two functional groups of pectins (carboxyl and hydroxyl) the stronger coordination of metal cations is in carboxyl group as salts are formed in the process. Besides, the carboxyl group from the point of conception of hard and soft acids and bases [17] is a less hard base in comparison with the hydroxyl group and it forms firm bonds with acids taking intermediate position on hardness (mainly with the ions of d-metals (II)) and less firm bonds with hard acids (mainly with the ions of d-metals (III)).

Thus, comparing the bands shift in IR spectra of pectinates and pectins in general, we draw the conclusion that the most sufficient shift of bands is observed for the hydroxyls associated by hydrogen bond. It is explained by the fact that in pyranose cycles the atoms of hydrogen and oxygen are fixed while the atoms of hydrogen of hydroxyl groups have more freedom of movement and only hydrogen binding holds them back from rotating around CO ties.

Alginates of polyvalent metals. The characteristic absorption bands in IR spectra of alginates of polyvalent metals in comparison with sodium alginate are given in Table 4, the shift of these bands and the change of energy of hydrogen bonds are given in Table 5. In $3925-3700 \mathrm{~cm}^{-1}$ area the band splitting due to the vibration interaction of connected oscillators is observed, especially significant it is for $\mathrm{Co}^{2+}, \mathrm{Zn}^{2+}, \mathrm{Pb}^{2+}$ alginates. The band splitting in the IR spectra of alginates

Table 4. Characteristic absorption bands $\left(\mathrm{cm}^{-1}\right)$ in IR spectra of alginates.

\begin{tabular}{|c|c|c|c|c|c|c|c|c|c|}
\hline $\begin{array}{l}\text { Alginate } \\
\mathrm{Na}^{+}\end{array}$ & $\begin{array}{l}\text { Alginate } \\
\mathrm{Cu}^{2+}\end{array}$ & $\begin{array}{l}\text { Alginate } \\
\mathrm{Ni}^{2+}\end{array}$ & $\begin{array}{c}\text { Alginate } \\
\mathrm{Co}^{2+}\end{array}$ & $\begin{array}{c}\text { Alginate } \\
\mathrm{Zn}^{2+}\end{array}$ & $\begin{array}{l}\text { Alginate } \\
\mathrm{Mn}^{2+}\end{array}$ & $\begin{array}{l}\text { Alginate } \\
\mathrm{Pb}^{2+}\end{array}$ & $\begin{array}{l}\text { Alginate } \\
\mathrm{Fe}^{2+}\end{array}$ & $\begin{array}{c}\text { Alginate } \\
\mathrm{Cr}^{3+}\end{array}$ & $\begin{array}{c}\text { Possible attribution of bands } \\
\text { [8] [9] [11] [12] [13] }\end{array}$ \\
\hline 3883 & & & 3895 & 3928 & & 3924 & & & \\
\hline 3763 & 3775 & 3772 & 3769 & 3778 & 3775 & 3764 & 3772 & 3768 & $v(\mathrm{OH}$, associated by hydrogen bonds) \\
\hline 3646 & & & & & & 3652 & & & \\
\hline & & 2950 & 2896 & & & 2994 & 2986 & 2896 & \multirow{2}{*}{$v(\mathrm{CH})$} \\
\hline 2899 & 2872 & 2848 & 2845 & 2845 & 2845 & 2840 & 2850 & 2845 & \\
\hline 2797 & 2736 & 2737 & 2738 & 2738 & 2738 & 2738 & 2738 & 2736 & \multirow{2}{*}{$v\left(\mathrm{O}_{6} \mathrm{H}\right)$} \\
\hline 2365 & 2356 & 2365 & 2359 & 2368 & 2365 & 2356 & 2366 & 2356 & \\
\hline 1648 & $1663 ; 1603$ & 1648 & 1645 & 1646 & 1648 & 1644 & $1636 ; 1608$ & 1640 & $v_{\mathrm{as}}\left(\mathrm{COO}^{-}\right)+\delta\left(\mathrm{H}_{2} \mathrm{O}\right)$ \\
\hline 1453 & 1444 & 1468 & 1465 & 1454 & 1468 & 1458 & 1466 & 1450 & $v_{\mathrm{s}}\left(\mathrm{COO}^{-}\right)$ \\
\hline 1360 & 1378 & 1372 & 1372 & 1382 & 1381 & 1382 & 1378 & 1378 & $\delta(\mathrm{CCH})+\delta(\mathrm{COH}) ; v\left(\mathrm{COO}^{-}\right)$of $M M$ block \\
\hline 1306 & 1307 & 1306 & 1307 & 1307 & 1306 & 1306 & 1306 & 1306 & $v\left(\mathrm{COO}^{-}\right)$of $G G$ block \\
\hline 1198 & 1120 & 1195 & 1195 & 1156 & 1198 & 1158 & 1198 & 1195 & $v(\mathrm{CC}$ of pyranose cycle $)$ \\
\hline 1084 & 1081 & 1081 & 1081 & 1081 & 1081 & 1084 & 1084 & 1081 & \multirow{3}{*}{$v(\mathrm{CO}$ of pyranose cycle $)$} \\
\hline 1054 & 1054 & 1050 & 1050 & 1038 & 1054 & 1051 & 1054 & 1054 & \\
\hline 949 & 960 & 967 & 958 & 972 & 955 & 974 & 977 & 955 & \\
\hline 721 & 724 & 721 & 721 & 722 & 721 & 722 & 722 & 721 & \multirow{2}{*}{$\delta(\mathrm{CH})$} \\
\hline 628 & 619 & 628 & 631 & 620 & 629 & 632 & 628 & 629 & \\
\hline 526 & 511 & 526 & 517 & 517 & 529 & 558 & 530 & 520 & $x(\mathrm{CO})$ \\
\hline
\end{tabular}


Table 5. The shift of absorption bands and the change of energy of hydrogen ties of alginates of polyvalent metals.

\begin{tabular}{|c|c|c|c|c|c|c|c|}
\hline Alginates & $\begin{array}{l}\text { Band shift }{ }^{*} \\
(3763), \mathrm{cm}^{-1}\end{array}$ & $\begin{array}{c}\text { Decrease of energy of } \\
\text { hydrogen ties }, \mathrm{kJ} / \mathrm{mole}\end{array}$ & $\begin{array}{l}v_{\mathrm{as}}\left(\mathrm{COO}^{-}\right) \\
\mathrm{cm}^{-1}\end{array}$ & $\begin{array}{c}v_{\mathrm{s}}\left(\mathrm{COO}^{-}\right) \\
\mathrm{cm}^{-1}\end{array}$ & $\begin{array}{c}\Delta v\left(\text { as-s } \mathrm{COO}^{-}\right) \\
\mathrm{cm}^{-1}\end{array}$ & $\begin{array}{c}v(\text { CO of pyranose } \\
\text { cycle }), \mathrm{cm}^{-1}\end{array}$ & $\begin{array}{c}\Delta v(\text { CO of pyranose } \\
\text { cycle })^{*}, \mathrm{~cm}^{-1}\end{array}$ \\
\hline Alginate $\mathrm{Na}^{+}$ & & & 1648 & 1453 & 195 & 949 & \\
\hline Alginate $\mathrm{Pb}^{2+}$ & +1 & 0.02 & 1644 & 1458 & 186 & 974 & 25 \\
\hline Alginate $\mathrm{Cu}^{2+}$ & +12 & 0.34 & 1663 & 1444 & 219 & 960 & 11 \\
\hline Alginate $\mathrm{Zn}^{2+}$ & +15 & 0.43 & 1646 & 1454 & 192 & 972 & 23 \\
\hline Alginate $\mathrm{Cr}^{3+}$ & +5 & 0.14 & 1640 & 1450 & 190 & 955 & 6 \\
\hline Alginate $\mathrm{Mn}^{2+}$ & +12 & 0.34 & 1648 & 1468 & 180 & 955 & 6 \\
\hline Alginate $\mathrm{Fe}^{2+}$ & +9 & 0.25 & 1636 & 1466 & 170 & 977 & 28 \\
\hline Alginate $\mathrm{Co}^{2+}$ & +6 & 0.17 & 1645 & 1465 & 180 & 958 & 9 \\
\hline Alginate $\mathrm{Ni}^{2+}$ & +9 & 0.25 & 1648 & 1468 & 180 & 967 & 18 \\
\hline
\end{tabular}

Note: ${ }^{*}$ in comparison with sodium alginate.

of polyvalent metals is observed in a less degree than for pectinates. With the introduction of cations of polyvalent metals into the alginate molecule in IR spectra the band shift of valent vibrations of hydroxyl groups into the long-wave area is observed, thus testifying the rupture or weakening of hydrogen ties by the ions of polyvalent metals [11] [12]. The specified spectral changes were observed at all polyvalent metals under study.

While determining the correlation between the absorption bands of hydroxyl groups associated by hydrogen tie and the energy values of hydrogen ties in metal alginates in " $v_{i}=f\left(-U_{B C}\right)$ " graphic system $y=a+b x$ linear relationship was obtained in which $a=111.18, b=-2.86 \times 10^{-2}$. The interaction of vibrations of oscillators of alginate ions with the ions of polyvalent metals is the cause of high-frequency shifts of bands and the energy decrease. In case of comparison with the alginic acid the differences given in Table 5 would have been more sufficient. The row of the metal ions in the order of their influence on the decrease of energy of hydrogen ties is as follows: $\mathrm{Zn}^{2+}>\mathrm{Cu}^{2+}=\mathrm{Mn}^{2+}>\mathrm{Ni}^{2+}=\mathrm{Fe}^{2+}>$ $\mathrm{Co}^{2+}>\mathrm{Cr}^{3+}>\mathrm{Pb}^{2+}$. The received data make it possible to assume that the ions of the above-mentioned metals, except for the ions of $\mathrm{Pb}^{2+}$, form coordination ties with the oxygen atoms of hydroxyl groups of alginates.

The value of $\Delta v\left(\right.$ as-s $\left.\mathrm{COO}^{-}\right)$quantity is more than $200 \mathrm{~cm}^{-1}\left(219 \mathrm{~cm}^{-1}\right)$ in $1660-1600 \mathrm{~cm}^{-1}$ and $1470-1440 \mathrm{~cm}^{-1}$ areas, characteristic for asymmetrical and symmetrical vibrations of ionized carboxyls in the molecule of $\mathrm{Cu}^{2+}$ alginate, testifies the formation of asymmetrical structures of $\mathrm{Cu}^{2+}$ ions with carboxyl groups of alginate acting as monodentate ligands. For the products of interaction of alginate ions with the ions of other polyvalent metals $\Delta v$ value is less than 200 $\mathrm{CM}^{-1}$, which proves the formation of symmetrical structures in which carboxyl groups of alginate behave as bidentate ligands. In comparison with the pectinates $\mathrm{Ni}^{2+}, \mathrm{Co}^{2+}, \mathrm{Mn}^{2+}, \mathrm{Fe}^{2+}$ alginates form more symmetrical structures.

In $1320 \mathrm{~cm}^{-1}$ area characteristic for the absorption of carboxyl groups of mannuronic blocks of alginic acid, for alginates of all metals the shift of the band 
into the long-wave part of the spectrum was observed: for $40 \mathrm{~cm}^{-1}$ for $\mathrm{Na}^{+}$ions and for $58-62 \mathrm{~cm}^{-1}$ for the ions of other metals; in comparison with $\mathrm{Na}^{+}$alginate this shift is $12-22 \mathrm{~cm}^{-1}$. Most intensively the mentioned band appeared with $\mathrm{Cu}^{2+}$ и $\mathrm{Fe}^{2+}$ alginates. In $1290 \mathrm{~cm}^{-1}$ spectral area, which is characteristic for the absorption of carboxyl groups of guluronic blocks of alginic acid, the shift of the band into the long-wave part of the spectrum for $16-17 \mathrm{~cm}^{-1}$ for the alginates of all metals was observed; along with it the intensity of this band is mostly expressed for $\mathrm{Fe}^{2+}$ and $\mathrm{Ni}^{2+}$ alginates. The obtained data make it possible to draw the conclusion about the coordination of the metal cations of carboxyl groups of both blocks.

The shift of the band in $949 \mathrm{~cm}^{-1}$ area, characteristic for CO vibrations of pyranose cycle, into the long-wave part of the spectrum is mostly expressed (18 $\left.28 \mathrm{~cm}^{-1}\right)$ in the presence of $\mathrm{Fe}^{2+}, \mathrm{Pb}^{2+}, \mathrm{Zn}^{2+}, \mathrm{Ni}^{2+}$ cations. Apparently, the ions of these metals are additionally coordinated by the oxygen atoms of pyranose cycle.

For $\mathrm{Cu}^{2+}$ и $\mathrm{Fe}^{2+}$ alginates a band in $1600 \mathrm{~cm}^{-1}$ area was revealed, which proves that they contain crystallization water. The insolubility of alginates as well as that of pectinates, polyvalent metals in water testifies the formation of threedimensional net structures.

Thus, just as in the case with pectinates, in the molecules of the alginates of polyvalent metals the metal ions are coordinated to the oxygen atoms of hydroxyl groups, carboxyl groups, pyranose cycle and water.

\section{Summary}

1) Comparison of IR absorption spectra of the $10 \%$ suspensions polyuronides out in the presence of cations of polyvalent metals $\left(\mathrm{Pb}^{2+}, \mathrm{Cu}^{2+}, \mathrm{Zn}^{2+}, \mathrm{Cr}^{3+}, \mathrm{Mn}^{2+}\right.$, $\left.\mathrm{Fe}^{2+}, \mathrm{Co}^{2+}, \mathrm{Ni}^{2+}\right)$ has allowed to identify the influence of metals the displacement of the spectral bands characteristic of specific functional groups and structural fragments polyuronides. Such groups and sections are (listed in descending order of size of shift):

- hydroxyl groups, including hydrogen bonds associated with free or substituted hydroxyl groups (shift of bands in the longwave region); between the absorption bands of associates and the decrease of energy of hydrogen bonds revealed significant correlation;

- ionized carboxyl group (shear bands, asymmetric characteristic fluctuation in the short wavelength region, and bands characteristic of the symmetrical variation in the long-wave region); polyuronates $\mathrm{Pb}^{2+}, \mathrm{Zn}^{2+}, \mathrm{Cr}^{3+}, \mathrm{Mn}^{2+}, \mathrm{Fe}^{2+}$, $\mathrm{Co}^{2+}, \mathrm{Ni}^{2+}$ formed a symmetrical structure of metal ions with carboxyl groups (bidentate ligands), polyuronates $\mathrm{Cu}^{2+}$-asymmetric structures with carboxyl groups (monodentate ligands);

- water molecules;

- the oxygen atoms of the pyranose cycle;

- the oxygen atoms of carbonyl groups of ester groups;

- $\alpha$-glycosidic bond (affect only $\mathrm{Cr}^{3+}$ and $\mathrm{Co}^{2+}$ ).

2) A significant shift of the absorption bands in the IR spectra polyuronates 
metals compared to polyuronide, the decrease of energy of hydrogen bonds associated hydroxyl groups, reducing the intensity of the absorption bands characteristic of water, is evidence of the formation of polyuronide coordination bonds with metal ions. It is established that metal ions in polyuronates contact with oxygen atoms mainly hydroxyl and carboxyl groups and oxygen atoms of water molecules, pyranose cycle of the carbonyls of the ester groups of the $\alpha$ glycoside bond center. In coordination of metal cations by alginates are involved both units of the polymer: polyguluronate and polymannuronate.

3) Characteristic changes in the IR spectra of pectinates are more pronounced than in the IR spectra of alginates.

4) Used methodological approach to the study of the structure polyuronates metals can be extended to the metallic derivatives of the various other classes of organic substances.

\section{References}

[1] Alekseev, Y.Y., Garnovsky, A.D. and Zhdanov, Y.A. (1998) Complexes of Natural Carbohydrates with Metal Cations. Achievements of Chemistry, 67, 723-744.

[2] Kajsheva, N.S. (2012) Study the Configuration of Metal Centers in Polyuronatic Method of EPR Spectroscopy. Chemical-Pharmaceutical Journal, 46, 51-53.

[3] Kajsheva, N.S. (2004) The Study of Natural Polyuronides and the Production of Medicinal Agents on Their Basis. Doctor's Thesis, Pyatigorsk State Pharmaceutical Academy, Pyatigorsk, $47 \mathrm{p}$.

[4] Kompantsev, V.A., Kajsheva, N.S., Samokish, I.I., et al. (2002) The Method of Extracting Biologically Active Substances from Laminaria for Medical Use. USSR Patent No. 2194525.

[5] Knutson, C.A. and Jeans, A.A. (1968) New Modification of the Carbazole Analysis: Application to Heteropolysaccharides. Analytical Biochemistry, 24, 470-481.

[6] Lakatosh, B., Mayzel, Y. and Varyu, M. (1981) The Method of Producing the Complex of Metal Ion with Oligo- or Polygalacturonic Acids. USSR Patent No. 886750.

[7] Panov, V.P. and Zhbankov, R.G. (1988) Intra- and Intermolecular Interactions in Carbohydrates (Nonvalent Interactions and Conformations). Science and Technics, Minsk, 359 p.

[8] Usov, A.I. (1999) Alginic Acids and Alginates: Analytical Methods Used for Their Estimation and Characterisation of Composition and Primary Structure. Achievements of Chemistry, 68, 1051-1061.

[9] Deiana, S., Erre, I. and Micera, G., et al. (1980) Download Iron(III) Reduction by D-Galacturonic Acid. Part II. Influence of Uranyl(VI), Lead(II), Nickel(II), and Cadmium(II) Complexes Formation. Analytica Chimica Acta, 46, 249-258.

[10] Debongnir, P. (1987) An E. P. R. and Potentiometric Study of the Complexes of Copper Ions by Galacturonic Acid and Galacturonates. Carbohydrate Research, 170, 137-148.

[11] Tajmir-Riahi, H.A. (1986) Triadimefon Protects Bean Plants from Water Stress through Its Effects on Abscisic Acid. Journal of Inorganic Biochemistry, 26, 23-33.

[12] Tajmir-Riahi, H.A. (1985) Complexes of Dendrimers with Bovine Serum Albumin. Journal of Inorganic Biochemistry, 24, 127- 136.

[13] Filippov, M.P. (1990) The Nature of Ties in the Plant Tissue, the Structure and Infrared Spectra as the Basis of Classification of Pectic Substances. Doctor's Thesis, 
Kishinev State University, Odessa, 38 p.

[14] Lurye, Y.Y. (1989) Manual of Analytical Chemistry. Khimiya, Moscow, 448 p.

[15] Batsanov, S.S. (1971) Electronegativity and Effective Atomic Charges. Znaniye, Moscow, $83 \mathrm{p}$.

[16] Zhdanov, Y.A. and Alekseev, Y.Y. (2002) The Main Achievements of the Coordination Chemistry of Modified Polysaccharides. Achievements of Chemistry, 71, 1090 1102.

[17] Garnovsky, A.D., Vasilchenko, I.S. and Garnovsky, D.A. (2000) Modern Aspects of Metal Complex Synthesis. Main Ligands and Methods. Rostov-on-Don, 355 p.

Submit or recommend next manuscript to SCIRP and we will provide best service for you:

Accepting pre-submission inquiries through Email, Facebook, LinkedIn, Twitter, etc. A wide selection of journals (inclusive of 9 subjects, more than 200 journals)

Providing 24-hour high-quality service

User-friendly online submission system

Fair and swift peer-review system

Efficient typesetting and proofreading procedure

Display of the result of downloads and visits, as well as the number of cited articles

Maximum dissemination of your research work

Submit your manuscript at: http://papersubmission.scirp.org/

Or contact ajac@scirp.org 